\title{
TRANSFORMAÇÃO DE MODELO EDUCACIONAL DE NISSEI NA COMUNIDADE NIKKEI-BRASILEIRA. DE WAKON-HAKUSAI-RON AO HAKKON-WASAI-RON-
}

Koichi Mori

Introdução

Se o mundo, no período compreendido entre o século XIX e a primeira metade do século XX, era o mundo dos "estados-nações" pode-se dizer que, a partir da segunda metade do século XX até os dias de hoje, ele tem sido o da globalização, com "migrações" de pessoas, coisas, informações e capitais, ultrapassando as fronteiras dos "estadosnações" As "migrações" de pessoas ocorreram pelas mais variadas razões, mas, sempre, em busca de uma vida melhor. As "migrações" de uma nação e/ou região para outra nação e/ ou região fizeram com que as pessoas passassem a viver um cotidiano que lhes era estranho até então e começassem uma vida nova. Uma das grandes preocupações dessas pessoas que se deslocaram para outras localidades era, em meio à rotina do dia-a-dia, pensar sobre que tipo de formação dar a seus filhos. Isto é, que tipo de "ser humano" formar. É sabido que muitos nikkeis (japoneses e brasileiros de origem japonesa) foram trabalhar, a partir de meados da década de 80, no Japão, "a terra dos antepassados" ou "a terra-natal", sendo que lá vivem, hoje, mais de 300 mil deles. No início, no contexto desse fenômeno chamado de "dekassegui", homens e mulheres iam para lá sozinhos. Eles permaneceriam lá por um período relativamente curto (dois, três anos) e voltariam "triunfantes" ao Brasil, depois de terem juntado uma economia ou remetido uma boa soma de dinheiro para a família que havia ficado aqui. Tudo começou como uma estratégia transnacional de ascensão econômica, mas, com a reforma da Lei de Imigração e de Ajuda a Refugiados, em junho 
de 1990, o fenômeno "dekassegui" virou moda. As pessoas passaram a viajar com suas familias, ao invés de sós, e, além disso, o período de suas estadas se prolongou. Falase que hoje em dia muitos pensam em viver lá de forma permanente. Uma das grandes preocupações desses nikkeis é a mesma de todos que migraram e migram de sua terra-natal: a educação de seus filhos, isto é, que tipo de formação lhes dar. Há, também, o problema da ambigüidade em termos de estratégia ou a sua total ausência (ausência de estratégia). Tudo passa pela pergunta: "O que o Japão representa para os pais nikkeis?" Trata-se apenas da terra de "residência temporária" ou de residência permanente, onde continuarão a viver também no futuro? Enquanto suas posturas=estratégias ainda estiverem indefinidas, a estratégia referente à educação de seus filhos também deverá continuar ambígua, sempre sendo postergada, de modo que aos próprios filhos também não resta outra alternativa a não ser seguir convivendo com tal ambigüidade. Hoje, com os deslocamentos fáceis, graças ao desenvolvimento dos meios de transporte de massa e ao advento da internet, facilitando a manutenção da relação entre familiares, parentes e amigos, que ficaram ou vivem no país de origem, e a conseqüente globalização, deve ser dificil para os dekasseguis obrigarem-se a optar pela estratégia de se fixar em uma determinada localidade. Além disso, a instabilidade causada pelos contratos de trabalho sem vínculo empregatício também deve corroborar com a dificuldade de se tecer uma estratégia de permanência definitiva.

No presente trabalho, procurarei tratar do problema de educação dos filhos de nikkeis residentes no Japão, que, acredita-se, tenha se tomado uma grande questão, fazendo um paralelo com o que os imigrantes japoneses - que migraram para o Brasil há um século - vieram praticando em relação aos seus filhos. Durante um século, os imigrantes japoneses correram atrás, continuadamente, da formação a dar a seus filhos. Não seria exagero afirmar que isso se deu com os imigrantes sempre divididos entre duas nações - uma, a terra natal, Japão, e a outra, o país que os recebeu, Brasil - em meio a conflitos e contradições, que ora eram reconciliadas, ora eram negociadas, isso repetidas vezes. Em outras palavras, pode-se dizer que se tratava da construção de sua própria etnicidade (identidade étnica). Aliás, essa busca continua a ser perpetrada até hoje, não só no Brasil, como no Japão e em outros espaços transnacionais.

Neste trabalho, pretendo dar uma visão panorâmica da "história" dos imigrantes japoneses no Brasil, que se iniciou em 1908, através da estratégia de vida e identidade por eles adotadas e suas transformações. Em seguida, pretendo examinar o conteúdo e as características dos modelos de educação dos descendentes, que foram por eles selecionados e postos em prática. Em especial, quero examinar como determinados modelos foram adotados em cada fase, correlacionando-os com fatores que contribuíram sobremaneira para a escolha tanto das estratégias de vida como de educação. Fatores como no caso da intervenção dos governos tanto brasileiro como japonês, principalmente no que tange à política de assimilação cultural, em concordância com a onda nacionalista brasileira, que vigorou dos anos 20 aos anos 30 e outros. 
No presente trabalho, definirei, por conveniência e com base na teoria da etnicidade ${ }^{1}$, o modelo de educação adotado pelos imigrantes japoneses como algo que diz respeito à formação da figura do "nissei ideal" como ser humano ideal, fruto de negociações, conciliações e aglutinações das características do que é ser japonês, trazidas de sua "terra natal", Japão, e das características do Brasil, o país que os acolheu. Isso tudo tendo ocorrido com os imigrantes de certa maneira divididos entre as duas nações. A "figura idealizada" foi esculpida em especial por imigrantes intelectuais ou educadores. Nem é preciso dizer que, na base de tudo, está a questão do significado a ser atribuído à categoria do nissei: se japonês, se da colônia (comunidade nikkei) ou se brasileiro. Em outras palavras, pode-se dizer que essa figura do "nissei ideal" é uma percepção/interpretação resultante da visão da própria etnicidade. Os imigrantes japoneses da primeira geração projetaram a sua própria etnicidade na figura do tal "nissei ideal". Nos modelos de educação/formação dos mesmos, sempre existiu a questão das negociações e reconciliações entre as duas nações, que, na prática, giravam em torno de dois eixos: o primeiro, o sentido que se deveria atribuir a cada uma das línguas envolvidas - japonês e português - e, o segundo, até que ponto se permitir a "assimilação" à sociedade brasileira.

2. As estratégias de vida dos imigrantes japoneses, sua identidade e suas transformações

\footnotetext{
1. Neste trabalho, apoiei-me basicamente no conceito de etnicidade de Takashi Maeyama. De acordo com Maeyama: "Etnicidade é o critério de percepção e conhecimento das pessoas, bem como de intelecção do mundo e de classificação de seres humanos, sendo que na sua base está o princípio, não importa se cultural ou físico, a partir do qual atributos são obtidos (um ou mais) e através dos quais o indivíduo se vê ou vê o outro. Trata-se de Ascription e não, de Achievement. A identidade é um processo consciente através do qual se faz a classificação/definição do eu em relação ao outro, o que deve ser diferenciado, strictu sensu, de um mero ato de rotular o outro, do lado de fora, em "categorias", embora ambos sejam as duas faces, frente e verso, de um mesmo fenômeno. Quer seja a etnicidade, quer seja a identidade, as duas são uma questão de reconhecimento de categorias humanas, mas, como nos ensinam resultados de pesquisas fenomenológicas, a percepção, o conhecimento e a tomada de decisão são todos atos impossiveis de serem levados a cabo, caso descartemos valores, orientações, direcionamentos. Ver, conhecer/ reconhecer e classificar seres humanos são todos atos que realizamos com uma visão ética, sendo, todos, portanto, Condutas Morais, isto é, o processo de conhecimento/reconhecimento é na sua origem um processo político" MAEYAMA, Takashi. Ethnicity to Burajiru Niekkei-jin Bunkajinruigakuteki Kenkyu (Estudo Antropológico: A Etnicidade e os Nipo-Brasileiros), Tóquio, Editora Ochanomizu Shobo, 1996, p. 446.
} 


\section{Figura 1}

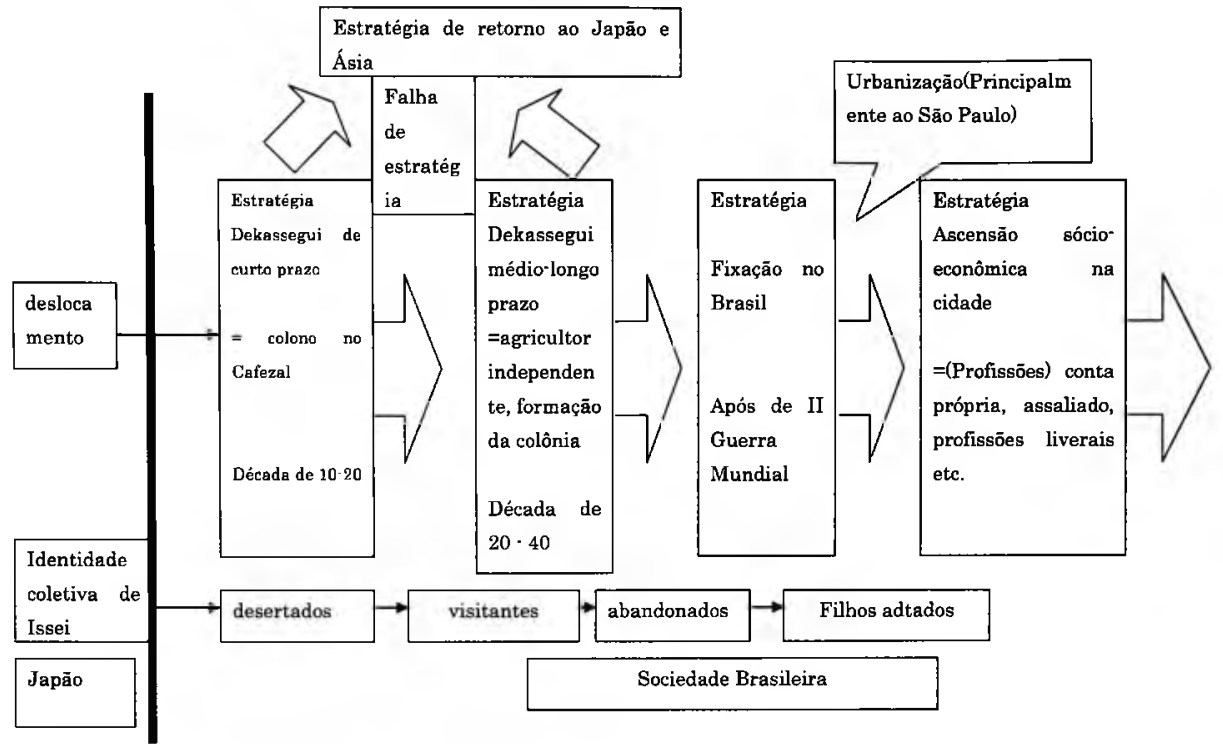

As estratégias de vida dos imigrantes japoneses no Brasil e suas transformações

A figura 1 é uma modificação que fiz, à minha moda, do modelo de estratégia de vida e de identidade apresentado por Takashi Maeyama em sua publicação, Imin no Nihon Kaiki Undô (O Movimento dos Imigrantes para Retornar ao Japão), de 1982. De acordo com Maeyama, os primeiros imigrantes tinham adotado originalmente a estratégia de curta permanência e breve retorno, isto é, vir ao Brasil, trabalhar como colono em fazendas de café e retornar depois de quatro ou cinco anos para o Japão, com os "baús feitos de palha, trazidos do Japão, cheios de dinheiro" Consta que todos eram dominados por esse pensamento=estratégia de vida (Maeyama batizou-a de a "estratégia da primeira fase de dekassegui", ou seja, juntar economia para em seguida retornar ao país de origem). Os imigrantes consideravam-se deserdados, já que não tinham o direito de herdar o patrimônio da família (no regime então vigente em vilas e aldeias do Japão, não lhes era permitido herdar os meios produtivos da família, por não serem primogênitos). $O$ modelo de identidade era o de "deserdados" Consideravam-se "visitas" isto é, "de passagem" por aqui, em casa de estranhos (Brasil), tendo iniciado a sua vida e o seu trabalho como trabalhadores agrícolas assalariados. No entanto, o trabalho de colono mostrou-se um trabalho escravo e era dificil atingir a meta inicial de trabalhar, ganhar dinheiro e voltar para o Japão. Os imigrantes, então, passaram a tecer novas estratégias, avaliando e tomando decisões de acordo com as diferentes 
situações com que se deparavam. Situações, como, por exemplo: o enfraquecimento da economia baseada no café, que causou o desmoronamento do regime de grandes latifúndios no estado de São Paulo, mas que, por sua vez possibilitou que os imigrantes passassem de colonos para proprietários de pequenos latifúndios; o início da industrialização de São Paulo, enriquecida com o capital acumulado pelo café e, com o crescimento/desenvolvimento de São Paulo, gerando o nascimento de outras capitais regionais. No centro da nova estratégia adotada estava a prorrogação do tempo de permanência no Brasil, de curto para médio a longo prazo, e deixar de ser colono e ascender socialmente, de colono para agricultor autônomo. Depois, passariam a viver em "shokuminchis" (colônias de imigrantes), por eles fundadas, num ambiente em que não precisariam se incomodar com a presença de "gaijins" (estrangeiros, isto é, os brasileiros). Investiriam mais tempo para juntar dinheiro e voltariam "triunfantes" para o Japão ("estratégia da segunda fase de dekassegui").

Entretanto, essa estratégia também acabou fracassando, diante do desmoronamento da economia do café, principal produto de exportação brasileiro na época, do clima antinipônico, do surgimento do sentimento nacionalista brasileiro, do estouro da Segunda Guerra Mundial, etc. Principalmente depois do início da Segunda Guerra Mundial e a conseqüente interrupção das relações diplomáticas entre o Brasil e o Japão e o fechamento de representações diplomáticas japonesas no Brasil, os imigrantes passaram a identificar a si próprios como "povo abandonado" ou "vítimas de guerra", adotando novas estratégicas de vida como estratégia de mudança de rumo, como o retorno ao Japão ou a re-imigração para as colônias de imigrantes. No entanto, essas estratégias não eram realistas e poucos foram os imigrantes que conseguiram adotá-las.

Após o término da Segunda Guerra Mundial, com a sensação de perda da pátria (país natal para o qual deveriam retornar), o crescimento dos filhos nisseis como "brasileiros" e o acúmulo de algum patrimônio durante o período da Guerra, os imigrantes adotaram uma nova estratégia, baseada na permanência definitiva no Brasil como estratégia de ascensão sócio-econômica em zonas urbanas. Com base nessa nova estratégia, os imigrantes migraram para cidades como São Paulo e arredores, passando a desenvolver a mencionada estratégia de ascensão social, como comerciantes ou assalariados administrativos/tecnocratas. Com a decisão da permanência definitiva no Brasil, ao invés da identidade de "visitante", optou-se pela do "filho adotado" Em outra simbologia, essa identidade é a identidade do "colôniajin" ("homem/gente da colônia" ou do "japonês do Brasil" Trata-se de criar uma distinção étnica/racial entre si e outros brasileiros, ao mesmo tempo em que, por outro lado, também cria uma distinção entre si e os japoneses do Japão, num processo de dupla diferenciação.

A estratégia de ascensão sócio-econômica funcionou de maneira efetiva até os anos 70 e imigrantes japoneses e seus descendentes=nisseis passaram a integrar a camada intermediária da sociedade brasileira. Entre eles, em especial os nisseis, passariam a 
participar de diversas áreas da sociedade, de maneira cada vez mais abrangente. Entretanto, na chamada "década perdida" brasileira, nos anos 80 , essa estratégia, praticada tanto por imigrantes japoneses isseis (da primeira geração) como por seus descendentes nisseis, perdeu a sua eficácia, resultando, como é sabido, o fenômeno "dekassegui" Iniciado em meados de 80, o fenômeno avolumou-se e tornou-se uma verdadeira febre após a revisão da Lei da Imigração e de Ajuda a Refugiados, no Japão, em junho de 1990. Pode-se chamar a estratégia dekassegui de "estratégia transnacional de ascensão sócio-econômica", surgida com o avanço da globalização e da reestruturação mundial da ordem econômica e trabalhistas (na prática, existiram, entre os dois países, diversos fatores push/pull (empurra/ puxa), que acabaram por promover o deslocamento transnacional da mão-de-obra brasileira para o Japão). Recentemente, os "dekasseguis" vão e voltam com freqüência (recorrência) ou estão prolongando a estada no Japão ou, ainda, estão considerando a estratégia de permanecerem no Japão definitivamente, levando ao aparecimento de novas identidades: a do "nikkei transnacional" ou a do "zainichi" (brasileiros residentes no Japão).

No presente trabalho, mostrarei os modelos de educação dos filhos de imigrantes japoneses no Brasil, desde o começo da imigração, em 1908, até o início dos anos 80 , fazendo uma correlação entre os mesmos e as transformações de suas estratégias de vida e de suas identidades. Farei isso salientando as localidades em que a primeira e a segunda fase da estratégia, bem como a fase da ascensão sócio-econômica pós-guerra ocorreram: respectivamente, lavouras de café, colônias de imigrantes e a cidade de São Paulo.

Periodo antes da Segunda Guerra Mundial: surgimento, desenvolvimento e negação do modelo de educação com base no modelo wakon hakusai ("espirito japonês e habilidades/técnicas brasileiras") 


\section{Figura 2}

\section{As situações em torno da educação dos descendentes antes da Segunda Guerra}

\section{Mundial e suas transformações}

\begin{tabular}{|c|c|c|c|c|}
\hline Período & Fase & Estratégia de vida & Situação & $\begin{array}{l}\text { Instituiçōes de } \\
\text { educação }\end{array}$ \\
\hline $\begin{array}{l}\text { 1908-final } \\
\text { anos } 10\end{array}$ & $\begin{array}{l}\text { Ausência de } \\
\text { educação de } \\
\text { descendentes }\end{array}$ & $\begin{array}{l}\text { Estratégia de dekassegui a } \\
\text { curto prazo, como colonos } \\
\text { Composição familiar } \\
\text { vantajosa para se ganhar } \\
\text { dinheiro (familias } \\
\text { compostas) } \rightarrow \\
\text { poucos filhos }\end{array}$ & $\begin{array}{l}\text { Modelo de povo por parte } \\
\text { do estado-nação brasileiro: } \\
\text { "embranquecimento" via } \\
\text { "miscigenação" } \rightarrow \text { reconheci- } \\
\text { mento de que se tratavam de } \\
\text { trabalhadores estrangeiros } \\
\text { temporários } \\
\text { Ausência de instituições de } \\
\text { educação nas lavouras de café }\end{array}$ & Ausentes \\
\hline $\begin{array}{l}\text { Início anos } \\
\text { 20-primeira } \\
\text { metade anos } 30\end{array}$ & $\begin{array}{l}\text { Surgimento da } \\
\text { educação dos } \\
\text { descendentes } \\
\text { (modelo "wakon } \\
\text { hakusai") }\end{array}$ & $\begin{array}{l}\text { Estratégia de dekassegui } \\
\text { a médio e longo prazo, } \\
\text { como agricultores } \\
\text { independentes } \\
\text { Formação de comunidades } \\
\text { étnicas regionais chamadas } \\
\text { de shokuminchi (colônias } \\
\text { de imigrantes) } \\
\text { Aparecimento, embora } \\
\text { em pouco número, de } \\
\text { imigrantes optantes pela } \\
\text { permanência definitiva no } \\
\text { Brasil. }\end{array}$ & $\begin{array}{l}\text { Intervenção do governo japonês } \\
\text { (imigração como política } \\
\text { nacional) } \\
\rightarrow \text { de "famílias compostas" para } \\
\text { "famílias comuns" } \\
\text { Aumento de imigrantes } \\
\text { japoneses } \\
\text { Modelo de povo do } \\
\text { Estado-Nação brasileiro: } \\
\text { "morenização" via } \\
\text { "miscigenação" = surgimento } \\
\text { do nacionalismo }\end{array}$ & $\begin{array}{l}\text { "Grupos } \\
\text { escolares } \\
\text { japoneses" }\end{array}$ \\
\hline $\begin{array}{l}\text { Segunda } \\
\text { metade anos } \\
30 \text {-inicio anos } \\
50\end{array}$ & $\begin{array}{l}\text { Dificuldades na } \\
\text { educação dos } \\
\text { descendentes } \\
\text { (negação do } \\
\text { modelo "wakon } \\
\text { hakusai"') }\end{array}$ & $\begin{array}{l}\text { Estratégia de dekassegui a } \\
\text { médio e longo prazo } \\
\text { Estratégia de retomo ao } \\
\text { Japão/Ásia (modelo, no } \\
\text { entanto, não-realista) }\end{array}$ & $\begin{array}{l}\text { Dois nacionalismos } \\
\rightarrow \text { (Brasil) Política de } \\
\text { assimilação dos imigrantes } \\
\rightarrow \text { (Japão) Política nacionalista } \\
\text { à distância com a criação do } \\
\text { conceito de "súdito" }\end{array}$ & $\begin{array}{l}\text { "Grupos } \\
\text { escolares } \\
\text { japoneses" }\end{array}$ \\
\hline
\end{tabular}

A figura 2 faz um resumo das diferent es situações em que se encontrava a questão da educação antes da Segunda Guerra Mundial. Examinaremos as seguintes fases: "Ausência/Inexistência de Educação dos Descendentes" (1908-primeira metade dos anos 20); "Surgimento da Educação dos Descendentes e seus Desdobramentos" (início dos anos 20-primeira metade dos anos 30) e, por fim, "Dificuldades na Educação dos Descendentes" (segunda metade dos anos 30-início dos anos 50). 
3 -(1) Ausência/inexistência de modelos de educação dos descendentes (1908-primeira metade dos anos 20) - fase das fazendas de café

\section{Figura 3}

Evolução do número de imigrantes antes da Segunda Guerra Mundial

\begin{tabular}{|c|c|c|}
\hline Período & $\begin{array}{c}\text { Números } \\
\text { absolutos }\end{array}$ & Porcentagem \\
\hline $1908-1912$ & 4672 & $2,5 \%$ \\
\hline $1913-1917$ & 14.767 & $7,9 \%$ \\
\hline $1918-1922$ & 12.394 & $6,7 \%$ \\
\hline $1923-1927$ & 24.976 & $13,4 \%$ \\
\hline $1928-1932$ & 56.976 & $30,6 \%$ \\
\hline $1933-1937$ & 65.685 & $35,3 \%$ \\
\hline $1938-1941$ & 6.811 & $3,7 \%$ \\
\hline Total & $\mathbf{1 8 6 . 2 7 2}$ & $\mathbf{1 0 0} \%$ \\
\hline
\end{tabular}

$\mathrm{Na}$ fase inicial da imigração, em 1908, quando os imigrantes da primeira leva chegaram ao Brasil como colonos e foram distribuídos em seis lavouras de café, até a primeira metade dos anos 20 , os imigrantes não estavam muito preocupados com a questão da educação de seus filhos. São alguns os motivos de tal despreocupação:

O primeiro: os que vieram na fase de colonos (a primeira colônia de imigrantes, 0 shokuminchi, só surgiu na segunda metade dos anos 10) eram em número muito pequeno, como podem ver pela figura 3 acima, isto é, os imigrantes não tinham filhos com que se preocupar. Ainda, na época, preponderava a estratégia de dekassegui, isto é, ganhar dinheiro e ir embora logo, e, para isso, os imigrantes tinham lançado mão da idéia da "família composta", formando famílias, digamos, postiças, "adotando "filhos" em idade de trabalho, situação mais vantajosa para ganhar dinheiro mais rápido, artifício baseado no peculiar sistema de registro civil japonês, diferente do brasileiro. Portanto, naquela fase, eram poucas as crianças em idade escolar. Essa situação está demonstrada nas figuras 4 e 5 .

A figura 4 mostra a composição das famílias japonesas que vieram para o Brasil antes da Segunda Guerra Mundial. Pode-se ver que a proporção de crianças no período que vai de 1908 a 1920, aproximadamente, é bem pequena em comparação ao período a partir dos anos 20. A figura 5 mostra o parentesco e a proporção dos membros integrantes da primeira leva de imigrantes da Ilha de Okinawa, composta de 325 okinawanos. De acordo com a figura, não existe um (a) único (a) filho (a) em relação de parentesco com os chefes de famílias. Esses números mostram o quanto as chamadas "famílias" eram 
compostas artificialmente no início da imigração, já que os primeiros imigrantes só estavam preocupados em ganhar dinheiro em curtíssimo prazo e logo retornar ao Japão.

\section{Figura 4}

Proporção dos imigrantes japoneses por período e por composição familiar

\begin{tabular}{|c|c|c|c|c|c|}
\hline & & $1908-1912$ & $1913-1917$ & $1923-1927$ & $1933-1937$ \\
\hline & asais & $34,6 \%$ & $37,3 \%$ & $21,3 \%$ & $18,5 \%$ \\
\hline & lhos & $21,8 \%$ & $22,6 \%$ & $46,8 \%$ & $48,2 \%$ \\
\hline Família & compostas & $42,1 \%$ & $39,9 \%$ & $26,2 \%$ & $27,5 \%$ \\
\hline & Parentes & $30,9 \%$ & $26,5 \%$ & $23,5 \%$ & $26,5 \%$ \\
\hline & Não-parentes & $11,3 \%$ & $13,4 \%$ & $2,7 \%$ & $1,3 \%$ \\
\hline & utros & $1,4 \%$ & $0,3 \%$ & $5,7 \%$ & $5,8 \%$ \\
\hline & otal & $100 \%$ & $100 \%$ & $100 \%$ & $100 \%$ \\
\hline Númer & $\mathrm{s}$ absolutos & 3.295 & 9.733 & 18.862 & 51.854 \\
\hline
\end{tabular}

Figura 5

Relação de parentesco dos 325 imigrantes da primeira leva de imigrantes Okinawanos

\begin{tabular}{|c|c|c|c|}
\hline Relação de parentesco & $\%$ & Relação de parentesco & $\%$ \\
\hline Chefe de família & 100 & Tio & 12 \\
\hline Esposa & 100 & Tio da esposa & 14,9 \\
\hline Primo & 289 & Irmão & 2,1 \\
\hline Primo da esposa & 123 & Sobrinha & 2,1 \\
\hline Irmão da esposa & 12,8 & Sobrinho da esposa & 4,3 \\
\hline Sobrinho & 14,9 & Pai & 2,1 \\
\hline
\end{tabular}


O segundo motivo era que, na esteira da estratégia de dekassegui, isto é, de ganhar dinheiro e logo ir embora, ainda que houvesse crianças em idade escolar, sua educação não era uma questão tão importante, já que a idéia era de irem todos embora para o Japão em poucos anos, não se sentindo qualquer necessidade de as educar.

Shungoro Wako escreveu o seguinte em relação à educação dos descendentes dos "imigrantes das lavouras de café":

"No início do ano 7 da Era Taisho, quando eu trabalhava na redação da revista Burajiru (Brasil), percorri a região de Ribeirão Preto, gastando pouco mais de quarenta dias, para realizar uma pesquisa sobre a questão da educação dos filhos dos imigrantes, isso por curiosidade pessoal. Nessa época, a maioria dos japoneses ainda não tinha conseguido sair das fazendas de café, de maneira que ainda moravam na região. Pesquisei umas quarenta e poucas fazendas, cerca de mil famílias, mas não havia uma sequer em que se ensinasse a língua japonesa. Pelo contrário, o desejo dos pais era que seus filhos aprendessem o português o quanto antes, mas o fato era que quase não havia escolas na região, a não ser nos grandes latifúndios ${ }^{2}$ "

De acordo com o depoimento de Wako, pode-se deduzir: a) que, mesmo nos fins dos anos 10 , não havia qualquer preocupação mais evidente com a educação dos filhos; b) que, motivados pelas limitações impostas pela língua, no dia-a-dia das fazendas de café, os pais preferiam que os filhos aprendessem o português, do invés do japonês, para mitigar tais dificuldades; c) que, como o próprio ensino do português já era dificil, na falta de escolas na maioria das fazendas, a não ser em grandes latifúndios, o que dizer, então, do ensino de uma lingua estrangeira como o japonês.

Vamos, agora, ao terceiro motivo: o próprio governo brasileiro, na época, estava muito mais preocupado em "embranquecer" o povo "morenizado" pela herança negativa, fruto da miscigenação, por sua vez fruto da escravidão, para construir um estado-nação europeizado, com uma única língua, uma única cultura e uma única etnia e não estava nem um pouco incomodado com os japoneses, já que estes não só eram reconhecidos apenas como mão-de-obra temporária, como também eram em pequeno número ${ }^{3}$.

3 - (2) Surgimento e desenvolvimento do modelo de educação wakon hakusaifase das colônias de imigrantes

\section{(1) O que estava por trás do modelo "wakon hakusai"}

O trabalho como colono nas fazendas de café era em substituição à mão-de-obra escrava, o que tornou praticamente impossivel que os imigrantes alcançassem o objetivo

2. WAKO, Shungoro. Bauru Kannai no Hojin (Japoneses da Regiäo de Bauru), 1939.

3. Consta que pelo menos a primeira e a segunda levas de imigrantes foram trazidos a título de "teste", como mão-de-obra temporária. 
inicial de "juntar economia" e "logo regressar triunfante à pátria" ou de "remeter dinheiro para os familiares que tinham permanecido no Japão" Por outro lado, a estrutura sócioeconômica embasada na produção e exportação do café, que vigorava desde a metade do século XIX, esmoreceu gradativamente a partir dos anos 20, o que ensejou a derrocada da oligarquia rural, baseada no regime dos grandes latifúndios. Derrocada esta, agravada pela quebra da bolsa em 1929, possibilitando que os imigrantes japoneses comprassem o seu pedaço de terra. Com isso, eles optaram por uma nova estratégia de vida, no lugar da de dekassegui a curto prazo. Na nova estratégia, a principal característica era a de que não eram mais colonos, mas agricultores autônomos, proprietários de pequenas terras em colônias de imigrantes fundadas por eles mesmos, onde viveriam e trabalhariam, sem serem incomodados pelos gaijins. A estratégia tinha passado a ser de médio a longo prazo. Nesse período, tentariam amealhar uma soma de dinheiro para, depois, alcançar os objetivos iniciais, isto é, retornar ao Japão.

Nessa época, a permanência dos imigrantes no Brasil tinha se tornado mais longa e muitos tiveram filhos, que já estavam em idade escolar ${ }^{4}$. Essa situação fez surgir as preocupações e também as necessidades em relação à educação dos descendentes.

Por outro lado, é preciso registrar que, nessa mesma época, aumentou o número de imigrantes japoneses no Brasil. Alguns fatores explicam esse incremento, a partir da década de 20.

O primeiro tinha sido a proibição, por parte do governo italiano, do envio de imigrantes subsidiados pelo governo de São Paulo devido às más condições de trabalho e aos atrasos no pagamento de salários. Havia, também, a dificuldade desses imigrantes de origem italiana de deixar de serem colonos e adquirirem a condição de pequenos agricultores independentes. Com isso, as fazendas de café do estado de São Paulo estavam enfrentando uma séria falta de mão-de-obra, que seria, então, suprida pelos japoneses.

O segundo, era a situação econômica japonesa, que estava se deteriorando a olhos vistos, assolada por uma longa recessão. Algumas de suas causas: primeiro, a Guerra RussoJaponesa, que arrastou o Japão à recessão, de 1905 a aproximadamente 1913, principalmente na zona rural do país. Além disso, houve, em 1918, o Levante do Arroz. Em 1920, ocorreu uma recessão ainda maior, na esteira do crack da Bolsa de Valores de Nova Iorque. E, em 1923, mais uma grande tragédia abateu-se sobre o Japão: o Grande Terremoto de Kanto. Diante desse quadro, o governo japonês passou a incentivar a emigração, como uma das saídas da crise, mas o problema era que cada vez menos países aceitavam imigrantes. Em 1907, por exemplo, foi assinado o Acordo de Lemieux com Canadá, que restringiu a entrada de imigrantes japoneses

4. Não eram poucos os antigos membros das "famílias compostas" que, tendo as deixado, tinham, agora, constituído as suas próprias. 
naquele país. No ano seguinte, em 1908, firmou-se um acordo de cavalheiros, desta vez com os EUA, que fez com que os próprios japoneses se limitassem a entrar naquele país. Lá, um forte sentimento anti-nipônico, que já existia há algum tempo, levou o país a fechar as portas por completo para os japoneses em 1921. Diante de toda essa situação, o Japão passou a dar atenção a países sul-americanos, principalmente ao Brasil. Foi assim que o governo japonês foi preparando terreno para fazer do envio de imigrantes japoneses para o Brasil uma "política de estado", o que levou ao já mencionado incremento 5 (Figura 3).

Nessa nova modalidade de emigração para o Brasil, de "esquema estatal", o governo japonês tratou de evitar as "famílias compostas" para apagar o "olhar de estranhamento" que elas haviam suscitado no passado, na sociedade brasileira, incentivado a emigração de "famílias normais", constituídas de casais, seus filhos e seus pais (dos casais) ${ }^{6}$. O resultado desse estímulo pode ser visto claramente na figura 4. Nessas "famílias normais", incluíase um grande número de crianças. A educação dessas crianças e mais a dos nisseis, que nasceram no Brasil, como resultado de uma maior permanência no país, passaram a ser de grande preocupação dos imigrantes japoneses da primeira geração.

\section{(2) Surgimento do modelo "wakon hakusai"}

Com as já mencionadas mudanças no formato da imigração japonesa no Brasil, a questão da educação dos filhos passou, "subitamente", a constituir um "grande problema" para os imigrantes japoneses aqui radicados. Shungoro Wako escreveu o seguinte a respeito da situação então vigente, nesse tocante:

5. A "estatização" da imigração, isto é, a imigração como política de estado começou com o estabelecimento oficial da rota marítima sul-americana e da abertura do Consulado Geral do Japão em São Paulo, em 1915. Em 1917, estabeleceu-se Kaigai Kôgyô Kabushiki Kaisha (Sociedade de Desenvolvimento Internacional), que reunia sob um único guarda-chuva várias companhias privadas de imigração, com capital de 10 milhões de ienes, unificando os processos e os trâmites referentes à imigração para a América do Sul. A partir de 1925, todas as despesas de viagem, bem como outras taxas, passaram a ser bancadas pelo governo japonês, no caso de a emigração ter como destino o Brasil. Em 1927, construiu-se a Imin Shuyojo (Hospedaria de Imigrantes) na cidade de Kobe, onde imigrantes eram preparados e treinados para viajar para o Brasil. Ainda em 1927, promulgou-se a Kaigai Ijûu Kumiaihô (Lei das Cooperativas de Emigração Ultramarina ) e no ano seguinte, em 1928, estabeleceu-se a Kaigai Ijû Kumiai Rengaôkai (Federação das Cooperativas de Emigração Ultramarina) e, assim, foi se consolidando cada vez mais, de maneira pró-ativa, o esquema de envio de imigrantes para a América do Sul.

6. Ainda pelo fato de a "política de estado" estar relacionado à promoção da agricultura independente, devido à polêmica em torno do regime de colonos, no passado, as Kaigai Ijû Kumiai (Cooperativas de Emigração Ultramarina) construíram os shokuminchis, colônias de imigrantes, meio estatal, de forma que, desta vez, os imigrantes entrariam desde início na qualidade de agricultores independentes. Assim, objetivava-se, também desde o início, a permanência definitiva no Brasil. Ademais, a partir dessa época, como escreveu Tomoo Handa, em 1970, da leva fazia parte os chamados "imigrantes intelectuais". Eram chamados de "imigrantes intelectuais" aqueles que tinham formação universitária e que tinham vindo para o Brasil com a intenção, desde o início, de aqui permanecer em definitivo. Consta que eles tinham ideologia cosmopolita e eram favoráveis à assimilação cultural. 
"Assim que a febre das colônias de imigrantes cresceu, fazendo surgir um grande número de agrupamentos de japoneses lá e acolá, a questão da educação dos filhos ganhou força, passando a ser o problema central desses núcleos de imigrantes. No entanto, por um bom tempo, continuou-se a discutir, sem se chegar a quaisquer conclusões, se a educação deveria ser brasileira, japonesa ou a combinação das duas" ${ }^{\text {"7 }}$

A questão da educação passou a ser discutida com fervor também nos jornais escritos em japonês, que tinham começado a circular por aqui já na segunda metade dos anos 10 .

Nessas discussões, sempre marcou presença um modelo de educação, o conhecido como "wakon hakusai" Esse conceito folclórico não era original dos imigrantes japoneses radicados no Brasil, mas, sim, um posicionamento que havia surgido no processo de modernização do Japão, após a Restauração Meiji: "wakon yosai", isto é, "espírito japonês e habilidades/técnicas ocidentais", adaptado à "realidade" dos imigrantes no Brasil. O que se discutia, tendo como premissa básica o reconhecimento dos nisseis como uma categoria à parte, era como negociar, conciliar e conjugar a "característica de ser japonês" com a "característica de ser brasileiro" (no caso dos nisseis) ou a "característica do que é ser um japonês residente no Brasil". Em outras palavras, o modelo "espírito japonês e habilidades/técnicas brasileiras" nada mais era do que o processo de construção de uma etnicidade, com base em uma educação bilíngüe, em que se discutia até que ponto permitir-se-ia a "assimilação" ao Brasil dos filhos nisseis ou das crianças imigrantes, que ensino priorizar, se baseado no japonês ou no português, que papel atribuir a cada uma dessas línguas ou como conjugar as duas, etc.

Havia algumas variações do modelo "espírito japonês e habilidades/técnicas brasileiras"

A primeira, o princípio do "Japão em primeiro lugar e Brasil em segundo", que estava estreitamente ligado ao fato de, na época, a grande maioria ter como estratégia de vida ganhar dinheiro e retornar, o quanto antes, "triunfantes", para o Japão. O objetivo era formar "japoneses que funcionassem no Japão", quando voltassem para lá, uma vez que a premissa era essa. Ou seja, evitar, tanto quanto possível, a assimilação e fazer com que os filhos tivessem não só, é claro, a capacidade de manejar o japonês, mas também que adquirissem virtudes, visão ética, cultura e valores puramente japoneses, como se fossem verdadeiros japoneses ${ }^{8}$ Por outro

7. WAKO, Shungoro. BAURU KAN'NAI NO HÔJIN (Japoneses da Região de Bauru), 1939, p. 52.

8. A primeira vez em que a discussão sobre a educação dos descendentes apareceu nos jornais japoneses publicados na "comunidade nipônica residente no Brasil" (o primeiro jornal japonês que surgiu em 1916) foi em 1921, no Burajiru Jihô (Atualidades Brasileiras), publicação que tinha o caráter de ser o boletim oficial da Kaigai Kôgyô Kabushiki Kaisha, a Sociedade de Desenvolvimento Internacional. O artigo dizia que no ensino brasileiro, faltava a "Educação Moral e Cívica" e que para resolver esse problema era necessário que a comunidade japonesa editasse a sua própria Cartilha de Moral e Cívica. Depois desse artigo, muitos outros tratando do mesmo assunto começaram a aparecer nos jornais japoneses publicados no Brasil. 
lado, embora não se renegasse a educação dada em português, esta era relegada ao segundo plano, isto é, ela (na verdade o ensino oficial) era apenas secundária e o português deveria ser compreendido como uma "língua estrangeira", sendo suficiente apenas a sua inteleç̧ão prática, funcional e técnica, só para evitar problemas do dia-a-dia. Isto é, no modelo em questão, o espírito japonês deveria ser $>$ (mais importante) que as habilidades/técnicas brasileiras, dandose maior importância ao primeiro, em detrimento do segundo, já que as habilidades/técnicas brasileiras deveriam ficar apenas no nível de não causar inconvenientes no dia-a-dia brasileiro (dar ordens aos empregados, manter contato com o mundo fora de casa, etc.).

A segunda variação do "wakon hakusai" era a defendida não por imigrantes de maneira geral, mas pelos ditos intelectuais (jornalistas, em sua maioria), além de moradores de zonas urbanas, aqueles bem-sucedidos e, também, pelo governo japonês, isto é, a "elite" japonesa residente no Brasil. Tratava-se do princípio do "Brasil em primeiro lugar e Japão em segundo" Esse modelo tinha como premissas a "permanência definitiva no Brasil" e a consciência de que os "nisseis eram cidadãos brasileiros nascidos no Brasil", conceitos que já tinham sido maturados por essas pessoas, que davam a devida importância à educação oficial brasileira.

Nesse modelo, propunha-se que não bastava o ensino apenas em "Hôjin Shôgakkô" isto é, "grupos escolares japoneses", sobre o qual comentarei mais tarde mais detalhadamente, e que era preciso prosseguir nos estudos em uma escola brasileira ${ }^{9}$. Entretanto, ao mesmo tempo, esse modelo não renegava o ensino do japonês: o objetivo era que, por seu intermédio, que seria um ensino suplementar, fora das escolas, virtudes e valores japoneses fossem incorporados pelos nisseis. Considerava-se o português o "vernáculo" dos nisseis, mas seu aprendizado seria essencialmente de cunho prático e/ou técnico: o nissei tinha que ter, acima de tudo, um "caráter" que "prezasse e incorporasse virtudes e valores japoneses" Portanto, em relação ao idioma japonês, havia a consciência de que também ele tinha o papel de "vernáculo". dividindo com o português a função de formação de caráter.

\section{(3) O dilema da educação baseada na dualidade: os "Hôjin Shôgakkôs" ("grupos escolares japoneses")}

Pode-se dizer que as colônias de imigrantes eram comunidades étnicas exclusivas e excludentes que os imigrantes japoneses fundaram a partir da segunda metade dos anos

9. Não havia escolas de nivel avançado nas colônias de imigrantes e os pais mandavam os filhos estudarem em São Paulo ou em cidades da região. No caso de São Paulo, surgiram, desde a década de 20, internatos para esse fim, sendo que nos anos 30, fundou-se a Seishi Gakusei Kishukusha Kyoôkai, Associação dos Intematos Estudantis da Cidade de São Paulo. A Associação publicou, em 1938, um manual denominado Seishi Yugaku no Tebiki (Manual para Estudar em São Paulo), em que se enfatizava o modelo "Brasil em primeiro lugar e Japão em segundo" (isto é, "wakon hakusai"), muito embora o manual trouxesse, também, informações práticas sobre o ensino médio el ou especializado em São Paulo. 
10. Depois de terem conseguido deixar a condição de "colonos" também tinham o papel de bloquear a "assimilação cultural", já que era onde se praticava o modelo de ensino "Japão em primeiro lugar e Brasil em segundo". A diferença decisiva entre as fazendas de café e as "colônias de imigrantes" era que nestas tinham sido fundados "grupos escolares japoneses", que eram instituições de educação voltadas exclusivamente para os filhos de imigrantes e onde se praticava o modelo de ensino "Japão em primeiro lugar e Brasil em segundo"

Assim, em muitas colônias de imigrantes recém-fundadas foram sendo erguidos grupos escolares japoneses com capital próprio. Na maioria das vezes eram "toscos", já que, recém-fundadas, as colônias não dispunham de recursos e, portanto, os grupos escolares tinham que ser baratos. Em alguns casos, "só imigrantes que tinham filhos em idade escolar pagavam o salário dos professores", que, aliás, eram recrutados entre os próprios imigrantes. Em outros casos, "os professores davam aula só pela manhã e, à tarde, trabalhavam como lavradores" Noutros, ainda, "pedia-se a algum recém-chegado do Japão, donas de casa ou rapazes, que servissem de professores" No caso das colônias de imigrantes que cultivavam café, só se conseguiriam recursos suficientes para as escolas, dentro de quatro ou cinco anos, depois que o café vingasse. Após a primeira colheita do café, "grupos escolares foram doados ao município ou ao estado e estes os administravam" e "as escolas passaram a ser reconhecidas oficialmente pelo poder público, com a contratação de professores brasileiros devidamente qualificados" Assim, depois de quatro ou cinco anos após a fundação de colônias de imigrantes, os grupos escolares japoneses tinham conseguido o status de "escolas oficiais" isto é, "escolas mistas de ensino primário da zona rural" colocando em prática uma educação bilíngüe(português e japonês). Isto é, de manhã, eram "escolas brasileiras", com currículo em português, de acordo com as leis brasileiras, e, à tarde, "escolas japonesas", em que se ministravam, em caráter de educação complementar, aulas em japonês.

Essas escolas japonesas eram freqüentadas por alunos de todas as idades. Um artigo do Burajiru Jihô (Atualidades Brasileiras) descreve-as assim:

"As escolas japonesas de nível fundamental imitam, em sua maioria, o sistema japonês, com seis anos de duração, sendo que algumas escolas possuem também o nivel médio. As matérias são: Vernáculo, Educação Moral e Cívica, Aritmética, Geografia, Ciências, Educação Física e Canto. Como se usam livros didáticos publicados no Japão, muitas vezes nem todos os alunos, nascidos no Brasil, conseguem compreender muito bem o conteúdo das aulas. As aulas em português são todas dadas em cumprimento às normas de ensino do estado de São Paulo, inclusive no que diz respeito ao currículo. As aulas são dadas separadamente, de manhã e de tarde ${ }^{10}$."

10. Burajiru Nenkan (Anuário Brasileiro), Burajiru Jihô Sha (Editora Atualidades Brasileiras), 1939, p. 108. 


\section{Figura 6}

Presença de w japonesas oficiais de nivel primário (abril de 1932)

\begin{tabular}{|c|c|c|c|c|}
\hline \multirow{2}{*}{ Categoria } & \multirow{2}{*}{ Quantidade } & \multicolumn{3}{|c|}{ Número de professores } \\
\cline { 3 - 5 } & & De japonês & De português & Total \\
\hline Estadual & 24 & 22 & 23 & 45 \\
\hline Estadual/Privada & 23 & 27 & 23 & 50 \\
\hline Privada & 54 & 75 & 46 & 121 \\
\hline Não-oficial & 27 & 34 & 13 & 47 \\
\hline Municipal & 18 & 18 & 20 & 38 \\
\hline Municipal/Privada & 10 & 11 & 15 & 26 \\
\hline Sem registro & 31 & 24 & 1 & 25 \\
\hline Total & 185 & 211 & 141 & 352 \\
\hline
\end{tabular}

(Fonte: Burajiru Nihonjin Imin Hachijyunenshi (História dos Oitenta Anos da Imigração Japonesa no Brasil), 1991

\section{p. 118)}

Essas escolas japonesas, tendo como expoente maior o Taishô Shôgakkô, Grupo Escolar Taisho, fundada em 1959, em São Paulo, totalizavam 30 até 1927, na jurisdição do Consulado Geral do Japão em São Paulo, e 31, na jurisdição do Consulado do Japão em Bauru. Em junho de 1931, o número de escolas japonesas tinha aumentado para 122, com 5.000 alunos e 200 professores ( 70 brasileiros e 130 japoneses). Em abril de 1932, eram 185 escolas (figura 6) e em março de 1939, 486, o que fazia constatar o aumento acelerado das colônias de imigrantes.

Nos "grupos escolares mistos" (esse era o nome oficial dos grupos escolares japoneses), os cursos duravam de três a quatro anos, mas em muitos casos a duração era de seis anos, seguindo os moldes japoneses, levando-nos a concluir que a estrutura toda era mesmo voltada para dar importância ao aprendizado da língua japonesa e de como ser japonês. 
Como já mencionado, nesses grupos escolares mistos, as aulas da parte da manhã eram em português, de acordo com o currículo estabelecido pelo governo estadual de São Paulo. À tarde, eram seis anos de estudo, com aulas de Japonês, Educação Moral e Cívica, Aritmética, Geografia, Ciências, Educação Física e Canto, todas ministradas em japonês e seguindo livros didáticos japoneses.

No entanto, os grupos escolares mistos - espaços destinados para formar nisseis de ideais híbridos tinham os seus conflitos e confrontos, de vários níveis.

O primeiro deles era a diferença entre o modelo de cidadão que o estado-nação brasileiro idealizava e o indivíduo híbrido hifenizado, nipo-brasileiro, idealizado pelos imigrantes. $\mathrm{Na}$ época, o modelo de cidadão ideal, sob a ótica brasileira, estava começando a migrar de uma visão "embranquecedora" para uma "morenizadora", em meio à "miscigenação", em pleno andamento. Esse modelo negava, claramente, a existência de cidadãos hifenizados de outras etnias (nipo-brasileiros, ítalo-brasileiros, etc.). A educação oficial brasileira evidentemente baseava-se nesse modelo de cidadão, batendo de frente com o objetivo dos imigrantes japoneses de formarem nisseis com "espírito japonês e habilidades/técnicas brasileiras"

Um artigo publicado no Burajiru Nenkan (Anuário Brasileiro), em 1938, diz o seguinte, quanto a esse confronto:

"Devemos nos atentar para as diferenças de didática, ideais, regras e treinamentos pedagógicos que existem entre os professores japoneses e brasileiros, o que leva a situações em que a orientação dada pela manhã por um professor pode ser derrubada inteiramente à tarde por outro. Isso, no final das contas, faz com que os alunos fiquem confusos quanto a que atitude tomar, criando, na extensão, antagonismos e rivalidades entre professores japoneses e brasileiros ${ }^{11}$ "

Havia também tensões e conflitos de outro nivel, ligados diretamente às peculiaridades das colônias de imigrantes, que inibiam a prática de um ensino bilíngüe. Nessa época, a língua do dia-a-dia, utilizada em casa, na vizinhança, isto é, na comunidade, era o japonês e o uso do português se restringia ao trato com os empregados, para dar ordens e/ou instruções. Ou seja, para a maioria das crianças e/ou alunos nikkeis, o português era como se fosse uma "língua estrangeira", apenas falada e aprendida na escola. Por outro lado, o japonês, a língua do dia-a-dia, era uma mistura de vários dialetos de diversas regiões de onde originavam os imigrantes. Além disso, esse japonês, que já não era o japonês padrão, ainda passou a tomar emprestados termos do português,

11. Burajiru Nenkan (Anuário Brasileiro), Burajiru Jiho Sha (Editora Atualidades Brasileiras), 1939, p. 108. 
o que o tornava uma "língua híbrida" (mais tarde, esse "japonês" foi rotulado de "colônia-gôo", isto é, "língua da colônia", e passou a ser o símbolo lingüístico da identidade étnica dos japoneses do Brasil). Era, portanto, consideravelmente diferente do japonês padrão, então ensinado nas escolas. Em outras palavras, pode-se dizer que as colônias de imigrantes constituíam um mundo à parte, com uma série de restrições no que dizia respeito ao ensino completo de ambas as línguas. Tomoo Handa descreve essa situação na sua grandiosa obra, Imin no Seikatsu no Rekishi (O Imigrante Japonês - História de Sua Vida no Brasil), da seguinte forma:

"A professora (de português) começou a elogiar os alunos japoneses, dizendo que 'eram obedientes e era fácil lhes ensinar coisas", que 'eram bons em Aritmética' ou que 'desenhavam bem' Quando perguntei: 'E o português', querendo saber sobre o aprendizado do português, deu uma risadinha amarela e disse: 'Lêem bem e têm uma boa caligrafia, mas, como o senhor sabe, quando voltam para casa só conversam em japonês'... e não falou mais nada. Aí, então, voltei-me para o professor de japonês e perguntei: 'Então, é mais fácil eles aprenderem o japonês, certo?', ao que ele respondeu: 'Deveria ser. Não há tanto problema com crianças que conhecem o Japão, mas aqueles nascidos aqui, ler, até que lêem, mas parece que não estão lá entendendo muito bem o que estão lendo, só repetem como papagaios. Além disso, não necessariamente o japonês que aprendem aqui, na escola, é útil em casa, isso porque o japonês que os pais usam é ruim' Parecia ser um professor muito bom, mas não muito fluente no português, mas, ainda assim, disse, como se ficasse penalizado pelo que tinha dito a professora de português: 'Tudo difícil, tudo difícil'”'12."

Outro problema, também tratado na obra de Handa, era o fato de serem usados livros didáticos japoneses para educar nisseis, com o intuito de formar verdadeiros japoneses, quando os nisseis eram cidadãos brasileiros nascidos no Brasil, embora fossem de origem japonesa. Esse problema também já tinha sido apontado pelo Burajiru Nenkan (Anuário Brasileiro), vide nota de rodapé 10 .

(4) Fase das dificuldades - negação do modelo "wakon hakusai"- entre dois nacionalismos

Nos parágrafos anteriores, falei brevemente sobre alguns dos conflitos e confrontos do modelo bilíngüe de ensino. Creio, no entanto, que, ainda assim, pode-se dizer que a

12. HANDA, Tomoo. Imin no Seikatsu no Rekishi (O Imigrante Japonês - História de Sua Vida no Brasil), 1970, p. 617. 
formação de indivíduos hifenizados(nisseis nas colônias de imigrantes) alcançou algum êxito. Mas, o fato é que, na segunda metade dos anos 30, cresceu no Brasil a onda nacionalista, que tinha se iniciado desde os anos 20 , passando a existir uma forte política de assimilação dos imigrantes (política de nacionalização)como formação de um povo brasileiro sem hífen. Com isso, o modelo duplo adotado pelos imigrantes japoneses começou a enfrentar dificuldades em termos de implementação. A partir da segunda metade dos anos 30, estava cada vez mais dificil pôr em prática a educação para "ser japonês", que passava necessariamente pelo ensino da língua japonesa. Em dezembro de 1938, os departamentos de japonês dos grupos escolares mistos, encarregados das aulas em japonês, foram extintos e, em 1941, ficou proibida a circulação de jornais e publicações em japonês ${ }^{13}$, o que na prática levou ao colapso do modelo de educação bilíngüe, que visava à formação de indivíduos hifenizados.

É claro que, nessa época, anos 30 , também no Japão o nacionalismo assolava o país e dentre os imigrantes japoneses, cujo destino principal na época era o Brasil, havia muitos com tal ideologia nacionalista ${ }^{14}$. Por outro lado, o governo japonês também tinha passado a interferir fortemente na educação dos filhos dos imigrantes, com o objetivo de formar, em terras remotas, súditos japoneses de mentalidade nacionalista ${ }^{15}$.

Em meio a esses dois nacionalismos, o nissei acabou exposto diretamente a conflitos e confrontos. Em uma situação em que tinha sido impedido de se tornar um indivíduo hifenizado, foi-lhe exigido que se declarasse ou brasileiro ou japonês (ou seja, a negação do status de ser um brasileiro étnico). Os nisseis, em meio a essa situação, foram se dividindo

13. Com relação à política de nacionalização como política de assimilação de estrangeiros dessa época, há uma tese relativamente abrangente do autor do presente trabalho, Koichi Mori, denominado "Burajiru no Nihonjin to Nihongo (Kyôiku)", "Os Japoneses do Brasil e o Idioma Japonês (Educação em Japonêss)" In Kokubungaku: Kaishaku to Kanshô(Estudos Vernaculares: Interpretação e Apreciação), 2006, v. 71, n. 7.

14. "Acreditava-se que o único meio para que os descendentes herdassem as boas coisas japonesas era por intermédio do ensino da língua japonesa. Assim, houve um grande empenho para injetar nos descendentes, ainda que numa dimensão totalmente fora do ambiente em que viviam, coisas como: "Japão, país sagrado, de ininterrupta linhagem imperial, sem igual no mundo";:" "raça escolhida para conduzir o mundo"; "a eterna grande causa"; "Hakkô Ichiu (literalmente, oito cordões, um só teto, isto é, todo o mundo sob um único teto)"; "Tôa Kyoôiken (Esfera de Co-Prosperidade da Grande Ásia Oriental)"; "exército imperial invencível"; etc. Ideologias como "o imperador é o estado", "o imperador é nosso pai", "Japão, nação proeminente ", "os japoneses são filhos do imperador", "Japão, o país que se sobressai entre os demais países do mundo" já estavam incorporados pelos imigrantes japoneses isseis, mas quando o Japão mergulhou em uma situação de anormalidade, estes ficaram sentimentalmente ainda mais inclinados a reafirmá-las, como sendo algo que lhes pertencia". (Imin Nanajûnenshi (História dos 70 Anos da Imigração Japonesa no Brasil)), 1979. p. 77.

15. Tal interferência se dava, por exemplo, sob forma de doações para a construção dos "grupos escolares", bolsas de estudo e envio de professores. 
entre serem "brasileiros na sua intenção" ou "japoneses na sua intenção"16 17 Na prática, com a proibição do uso do japonês por mais de dez anos, já que ele tinha sido considerado uma língua inimiga, acelerou-se, entre os nisseis, a migração para o português.

\section{Periodo Pós-Guerra-Surgimento do modelo hakkon wasai(espirito brasileiro; habilidades/técnicas japonesas)}

\section{4-(1). Pano de Fundo}

Depois de uma fase confusa devido ao confronto "vitoristas x derrotistas", logo após o término da Segunda Guerra Mundial, os imigrantes japoneses aos pouco foram abandonando a estratégia dekassegui, predominante no período anterior à Guerra. Em seu lugar, estavam determinados a permanecer em definitivo no Brasil e, assim, foram procurando se ascender social e economicamente no país. Por trás dessa nova estratégia, havia vários fatores: (1) sentimento de perda da pátria para o qual retornariam, depois da derrota do Japão na Guerra; (2) a existência dos nisseis, que cresceram como "cidadãos brasileiros" sob a política nacionalista brasileira; (3) o fato de, com o grande boom do setor agrícola

16. "Os grupos escolares japoneses não eram espaços meramente voltados para o ensino da língua japonesa. Esperava-se que ali, tanto crianças como jovens, homens e mulheres, e, ainda, os pais viessem a se tornar verdadeiros "japoneses", "seres humanos" de verdade. Quem não participasse dos eventos ali promovidos não era considerado membro do grupo, nem era considerado japonês. As escolas japonesas eram administradas pela Nihonjinkai (Associação Japonesa) e em suas paredes repousava, obrigatoriamente, a foto do Imperador e da Imperatriz do Japão e também o Kyôiku Chokugo (Édito Imperial sobre Educação). Os grupos escolares japoneses não eram um lugar só para a educação dos descendentes, mas também para as reuniões da Associação Japonesa, bem como da Seinendan (Associação dos Jovens) e da Shojodan (Associação de Virgens), além de servir de escritório para as cooperativas agrícolas. Outras cerimônias e rituais como Shihôhai (cerimônia imperial, realizada todo dia 1 de janeiro), Kigensetsu (data comemorativa da entronização do Imperador Jinmu, celebrada todo dia 11 de fevereiro), Tenchôsetsu (aniversário do Imperador) também eram todos comemorados ali, além do aniversário da colônia e formaturas. Contavam com a presença não só de alunos, como de todos os integrantes da colônia de imigrantes e eram realizados com todo cerimonial e pompa que as ocasiões exigiam. Antes de quaisquer eventos acima, havia o Kôkyo Yôhai ou o Tôhô Yôhai (reverência em direção ao Palácio Imperial), que, em suma, tinha o sentido do Nippon Yohai (reverência ao Japão). Ademais, reverenciava-se a foto do Imperador e da Imperatriz, lia-se o Édito Imperial e, ainda, entoava-se o Kimigayo, o hino nacional japonês". MAEYAMA, Takashi. Ito ni Nippon wo Matsuru (Santificar o "Japão" em um País Estrangeiro), Tóquio, Editora Ochanomizushobô, 2001, p. 55.

17. A citação a seguir mostra bem a realidade do que é tornar-se "brasileiro na sua intenção". $\mathrm{O}$ artigo chamase "Warera no Shinjô" ("Nossos Sentimentos"), extraído do boletim denominado Gakuyú (Amigos dos Estudos), editado pela Sociedade Paulista de Estudantes, 1936: "... Temos verdadeiro orgulho de termos nascido na terra de Piratininga. Ainda que em nossas veias corra o sangue da raça japonesa, o nosso coração, isso sim, bate mais forte pelo amor à nossa pátria, Brasil. Prova disso foi que, na revolução de 1932, nós, nisseis, nos jogamos diante das fileiras formadas por policiais militares. Temos, assim, colocado em prática as nossas obrigações para com a terra de nosso nascimento, para com a nossa pátria. Como podemos amar a pátria de nossos pais, Japão, como podemos ter amor pátrio a um país tão distante e que não conhecemos?!..." 
durante a Segunda Guerra Mundial, muitos imigrantes terem construído patrimônio. Um dos objetivos da estratégia de ascensão sócio-econômica era tornar o nissei bem sucedido na sociedade brasileira em geral. Para isso, muitas famílias migraram para cidades como São Paulo, onde as condições de educação eram mais bem estruturadas, e abriram negócios, com o pequeno capital acumulado durante a Guerra, objetivando estabilidade econômica e ascensão social, com a ajuda solidária de seus familiares.

A migração dos nikkeis para cidades encabeçadas por São Paulo, zonas urbanas que pareciam aos olhos dos imigrantes mais vantajosas para a ascensão sócio-econômica com base no comércio, tornou-se cada vez mais freqüente a partir da década de 40 . Os imigrantes japoneses almejaram a ascensão social com os seus pequenos negócios e contaram com a força da mão-de-obra familiar. Esses negócios permitiam horários flexíveis, o que possibilitava que os filhos freqüentassem a escola nas horas menos apertadas. $\mathrm{O}$ fato de as escolas públicas, tanto municipais como estaduais, serem gratuitas e terem dois turnos também foi uma das condições que facilitou o acesso dos nikkeis ao ensino público brasileiro.

Diferentemente do que acontecia nos grupos escolares das colônias de imigrantes anteriores à Guerra, nas escolas públicas paulistas ou de outras cidades, os colegas de classe não eram somente japoneses, mas de diversas origens étnicas, com os quais os nikkeis passaram a interagir. Isso fez com que não só o uso do idioma japonês perdesse lugar na comunidade, como também constituísse uma das condições para que os nikkeis, principalmente os nascidos no Brasil e as crianças imigrantes, fossem se voltando cada vez mais para o português. Além disso, a Lei do Ensino Obrigatório, revisada em 1961, ampliou o período do ensino obrigatório de quatro para nove anos, acelerando ainda mais essa guinada para o português.

A seguir, na figura 7, há um resumo das principais condições e/ou pano de fundo em torno da educação dos filhos dos imigrantes japoneses no período pós-Segunda Guerra Mundial. 


\section{Figura 7}

\section{Condições em torno da educação dos descendentes no periodo pós-Segunda}

\section{Guerra Mundial}

\begin{tabular}{|c|c|c|c|}
\hline Período & $\begin{array}{l}\text { Características do modelo } \\
\text { adotado }\end{array}$ & Táticas de sobrevivência & Contexto/condiçōes \\
\hline $\begin{array}{l}\text { Anos 50- } \\
\text { Anos } 60\end{array}$ & $\begin{array}{l}\text { Importância do } \\
\text { ensino público } \\
\text { brasileiro (canal para } \\
\text { sucesso no Brasil) } \\
\text { Retomada } \\
\text { do ensino do } \\
\text { japonês=voluntário e } \\
\text { opcional } \\
\text { Regime duplo: } \\
\text { ensino público } \\
\text { em português e } \\
\text { complementar em } \\
\text { japonês(extinção dos } \\
\text { grupos escolares, } \\
\text { etc.) } \\
\text { Ensino } \\
\text { público=espaço } \\
\text { multi-étnico }\end{array}$ & $\begin{array}{l}\text { Estratégia de } \\
\text { permanência } \\
\text { definitiva no Brasil } \\
\text { e ascensão sócio- } \\
\text { econômica em zonas } \\
\text { urbanas (negócio } \\
\text { próprio, trabalho } \\
\text { assalariado e/ou } \\
\text { tecnocrata) } \\
\text { Avanço dos } \\
\text { nikkeis em zonas } \\
\text { urbanas=desapareci- } \\
\text { mento do idioma } \\
\text { japonês na } \\
\text { vizinhança, na } \\
\text { comunidade }\end{array}$ & $\begin{array}{l}\text { Aceleração da migração para o } \\
\text { idioma português, na educação } \\
\text { de nisseis, devido à corrente } \\
\text { nacionalista, predominante até o } \\
\text { início dos anos } 50 \\
\text { Fuga dos nisseis do "ser } \\
\text { japonês", devido à confusão } \\
\text { pós-guerra(disputa vitoristas x } \\
\text { derrotistas) } \\
\text { Reestruturação da comunidade } \\
\text { falante de japonês } \\
\text { Retomada da imigração pós- } \\
\text { guerra (que continuou até o fim } \\
\text { dos anos } 60 \text { ) }\end{array}$ \\
\hline Anos 70 & $\begin{array}{l}\text { Supra idem } \\
\text { Criação de } \\
\text { um esquema } \\
\text { transnacional de } \\
\text { envio de professores } \\
\text { de japonês } \\
\text { Interferência do } \\
\text { governo japonês } \\
\text { no ensino da língua } \\
\text { japonesa }\end{array}$ & $\begin{array}{l}\text { Permanência } \\
\text { definitiva e ascensão } \\
\text { sócio-econômica em } \\
\text { zonas urbanas } \\
\text { Nisseis avançam } \\
\text { para o nível superior } \\
\text { de educação, com } \\
\text { maior participação } \\
\text { na sociedade } \\
\text { brasileira em geral }\end{array}$ & $\begin{array}{l}\text { Avança o desuso do japonês } \\
\text { em casa } \\
\text { "Movimento de contracultura } \\
\text { (afirmação e recuperação dos } \\
\text { direitos de minoria, busca } \\
\text { de raizes, etc.); língua como } \\
\text { "direito"(volta do nissei ao "ser } \\
\text { japonês") }\end{array}$ \\
\hline Pós anos 80 & $\begin{array}{l}\text { Supra idem } \\
\text { Cresce a febre de } \\
\text { aprender japonés } \\
\text { Problemas com a } \\
\text { educação dos filhos } \\
\text { de dekasseguis } \\
\text { ( i n c l u i n d o } \\
\text { desencaminhamento } \\
\text { e ocorência de } \\
\text { crime) }\end{array}$ & $\begin{array}{l}\text { - "D e k as s e gui" } \\
\text { como estratégia } \\
\text { transnacional de } \\
\text { ascensão econômica }\end{array}$ & $\begin{array}{l}\text { - Ojaponês "desaparece" dos lares } \\
\text { e também de sociedades étnicas } \\
\text { - Fortalece-se o conceito de que } \\
\text { língua é "recurso" }\end{array}$ \\
\hline
\end{tabular}




\section{4-(2). As peculiaridades do ensino do japonês no periodo pós-guerra}

O ensino da língua japonesa, que tinha sido suspenso por lei, recomeçou em 1948, com a promulgação da Nova Lei da Educação, de novembro de 1947, que afrouxou as regras referentes ao ensino de línguas estrangeiras. A partir desse ano, na cidade de São Paulo, fundaram-se numerosas "escolas de japonês, oficialmente autorizadas pelo governo brasileiro" Em 1954, eram cerca de 30, número que, no início dos anos 60, pulou para algo em toprno de 600 .

Na metade dos anos 50, resolveu-se que se deveria fundar uma associação que arregimentasse escolas de japonês e assim foi feito: fundou-se a Nihongo Gakkô Rengôkai (Associação das Escolas de Japonês Reconhecidas pelo Governo do Estado de São Paulo) e, em julho de 1954, realizou-se a sua primeira reunião de comunicações. De acordo com o boletim Ikusanga (Vários Rios e Colinas), da Associação, ela foi realizada sob os auspícios do Consulado Geral Imperial do Japão, no lugar das reuniões promovidas antes da Guerra pela Bunkyô Fukyû Kai (Associação de Difusão de Cultura Japonesa) e com a "determinação de que o ensino da língua japonesa deve ser realizado com a força da própria comunidade" Essa atitude está estreitamente relacionada com o sentimento dos imigrantes japoneses da primeira geração que, como "japoneses do Brasil" ou como colônia-jin, tinham cortado o cordão umbilical com o Japão.

Depois dessa primeira reunião, outra foi realizada no ano seguinte, em janeiro de 1955, com a participação de 25 proprietários de escolas e professores, com o nome de Seish $\hat{u}$ Kônin Nihongo Gakkô Rengốkai Sôritsu Sôkai (Assembléia de Fundação da Associação de Escolas Japonesas Reconhecidas pelo Estado de São Paulo), assim oficializando a fundação da organização.

Essas escolas de japonês possuíam as características a seguir relacionadas, que as diferenciavam dos grupos escolares mistos de antes da Guerra: (1) diferentemente dos grupos escolares mistos das colônias de imigrantes, não eram bilíngües, ensinava-se unicamente o japonês; (2) a sua freqüência era voluntária (opcional); (3) as horas dedicadas ao ensino do japonês tinham diminuído (média de duas a três horas por dia, três vezes por semana, priorizando acima de tudo o "ensino oficial brasileiro" para que os descendentes "fossem bem sucedidos no Brasil"; (4) além de aulas de língua japonesa, havia aulas de Desenho, Trabalhos Manuais e música/canto. Ademais, promovia apresentações teatrais, bem como se realizavam gincanas poliesportivas, o que nos leva à conclusão de que essas escolas eram um lugar mais para se ensinar a "ser japonês" do que propriamente para se ensinar a língua japonesa. 


\section{4-(3). Do modelo wakon hakusai para hakkon wasai- "assimilação intermediária" e modelo de transmissão cultural}

Com a retomada do ensino do japonês, a partir do final dos anos 40 , os imigrantes japoneses criaram diferentes modelos de educação para seus filhos, todos tendo como premissa a permanência definitiva no Brasil. Esses modelos foram tecidos em torno de dois pilares, como antes da Guerra: (1) até que ponto permitir ou inibir a assimilação dos nisseis e (2) que papéis atribuir ao português e ao japonês, respectivamente. A diferença era que agora era importante o ensino oficial brasileiro, como uma condição para se "obter sucesso no Brasil" Outra diferença era o fato de a língua portuguesa ter sido reconhecida como vernáculo, embora, pelo menos logo depois da Guerra, ainda não tivesse ficado claro o papel do português como vernáculo de função formadora de caráter.

E, agora, vamos dar uma passada de olhos em alguns dos principais modelos de educação de descendentes colocados em prática no Brasil.

O primeiro modelo que surgiu logo após o término da Guerra foi aquele que, embora fosse calcado no wakon hakusai, procurava, ao mesmo tempo, formar "ilustres cidadãos brasileiros com espírito yamato (espírito japonês)"

Há, a seguir, um texto justificando a necessidade do ensino do japonês, extraído de um concurso de oratória em japonês, realizado em Três Vales, interior de São Paulo, sob o tema "Clamor ao Ensino do Japonês":

"Há três anos, comemoramos, no dia 15 de agosto, o dia da alegria, o dia em que a guerra santa em nossa pátria alcançou o seu objetivo. Demonstramos, nós, os 350 mil conterrâneos japoneses residentes no Brasil, a nossa gratidão e a nossa comoção à pátria e, em seguida, a nossa consciência étnica voltou-se novamente à importância do ensino do japonês aqui em terras brasileiras. No entanto, ao ver o meu próprio filho, aqui nascido, constatei que, mesmo aos 20 anos de idade, ele sequer sabe escrever seu próprio nome em japonês, devido ao abandono do ensino do japonês no Brasil durante o período da Guerra. Pode-se dizer o mesmo sobre os descendentes em geral, de sua capacidade de intelecção em japonês, já que o nível de ensino do idioma japonês, lamentavelmente, decaiu como um todo. Aqui anseio pelas providências a serem tomadas pelas autoridades competentes, bem como pela inspiração de cada um dos senhores pais e pela cooperação voluntária e espontânea dos jovens, afirmando que "não existe a raça/etnia japonesa sem o ensino da língua japonesa": o aprendizado do japonês é a única maneira para se conhecer o verdadeiro Japão. É preciso espalhar a quintessência do espírito japonês, através da língua japonesa. $E$ todos nós devemos nos esforçar para nos tornarmos brasileiros melhores, de origem japonesa!" 
Assim, surgiu, em 1950, a Zenpaku Seinen Renmei (Associação Brasileira de Jovens), que preconizava o ensino do japonês com o objetivo de propagar o espírito japonês. Dessa forma, do mesmo modo como ocorreu antes da Guerra, atribuiu-se à língua japonesa o papel de fermentar e amadurecer o espírito japonês, ou seja, foi-lhe agregado o papel de formador de caráter, exatamente como antes da Guerra. Vários fatores corroboraram para que essa proposta nacionalista se tornasse realidade, mesmo terminada a Segunda Guerra Mundial: o fato de os japoneses e seus descendentes nisseis terem nitidamente optado por se tornarem, em sua intenção, "japoneses", em confronto ao nacionalismo brasileiro; depois, o fato de, embora o Brasil fosse um dos países aliados, não ter aqui havido, em território brasileiro, ações bélicas diretas; e a inexistência de imposição externa por mudanças, como houve no Japão, como as Forças Americanas de Ocupação, isto é, o fato de o Brasil não ter passado por experiências concretas de guerra.

O segundo modelo surgido foi o da completa assimilação dos nisseis à sociedade brasileira, na qualidade de cidadãos brasileiros. A teoria era de que, para se obter sucesso no Brasil, não era necessário aprender o japonês ("teoria da não necessidade da educação em japonês"). Esse modelo podia ser dividido em: (1) "teoria de que aprender o japonês é prejudicial" e (2) "teoria de que era um ônus a mais para a criança nikkei" Era uma forma de os imigrantes japoneses mostrarem estar em sintonia com a "política nacional" de construção de um estado-nação, baseado no princípio da assimilação total, em voga no Brasil no período que vai dos anos 30 até logo depois do término da Segunda Guerra Mundial. Em outras palavras, tratava-se do modelo hakkon wasai.

No entanto, esses dois modelos não foram muito bem aceitos pela "comunidade nikkei" radicada no Brasil, a chamada "colônia nikkei" O modelo mais aceito pela colônia nikkei foi o proposto por Zenpachi Ando ${ }^{18}$. Sua instância era a de propor a educação japonesa como meio de herdar as técnicas e habilidades, a cultura e a escala de valores dos imigrantes japoneses e, com

18. "Não se pode compreender corretamente o principal objetivo do ensino do japonês, se não se definir, de maneira clara, quem é o nissei ou o que ele representa para a colônia nikkei. O nissei é, para seus pais, seu filho. Mas, no Brasil, o imigrante issei, da primeira geração, é um estrangeiro, ao passo que seu filho, o nissei, é um brasileiro nato. Mantêm uma relação de estrangeiros e brasileiros, mas, ao mesmo, de pais e filhos, do ponto de vista do sangue, compondo um grupo social bastante peculiar, chamada de colônia nikkei. Só quando a colônia nikkei for construída sobre uma cooperação sólida entre os isseis e os nisseis é que a imigração da etnia japonesa para o Brasil terá tido algum sentido. Para estreitar os laços entre os isseis e os nisseis e fazer com que a cooperação entre os dois seja perfeita, está, acima de tudo, a língua. Além do mais, essa língua tem, obrigatoriamente, que ser o japonês, para transmitir aos brasileiros e ao Brasil, através dos nisseis, a excelência do talento e da técnica dos isseis e também a boa cultura do Japão, seu país natal. Pensando dessa forma, não basta que os nisseis sejam bons brasileiros. O nissei, ao mesmo tempo em que tem que ser um bom brasileiro, tendo como país natal o Brasil, tem também que compreender os sentimentos do issei e ser um bom filho de japonês e ser profundamente interessado pela cultura japonesa. Só assim, a instância e peculiar do nissei pode vir a se tornar uma gloriosa existência na sociedade." (ANDO, Zenpachi. Nisei to Nippongo Mondai-Koronia no Ryôshiki ni Uttaeru (O Nissei e a Lingua Japonesa: Um Apelo ao Bom Senso da Colônia), São Paulo, edição própria, 1958, p. 28). 
isso, formar "cidadãos brasileiros de peso" que pudessem contribuir para o desenvolvimento da sociedade brasileira. Ou seja, a educação japonesa seria um meio de "transmissão da cultura japonesa" O posicionamento de Ando era uma combinação de duas instâncias: a instância dos que preconizavam que "os nisseis também eram japoneses com sangue japonês", isto é, partidários do "princípio Nippon (Japão)" + dos que diziam que "os nisseis eram brasileiros", isto é, partidários do "princípio da assimilação total", criando uma nova figura do nissei(colôniajin ) (com base na premissa um cidadão brasileiro). Este, como "brasileiro", deveria ser um "brasileiro de peso", capaz de transmitir a "boa cultura da pátria, o Japão", aos brasileiros, ao mesmo tempo em que, juntamente com os imigrantes isseis, fosse "membro da colônia nikkei" e, como colônia-jin, fosse o sujeito, solidário e cooperativo, esforçando-se para o seu desenvolvimento (da colônia nikkei). A espinha dorsal da tese de Ando era de que os nisseis ocupavam uma "posição peculiar" e que para que eles pudessem aprender a "excelência, trocar a ordem, em termos de talentos e técnicas, dos isseis e, ainda, a boa cultura da terra-natal, Japão" e, com isso, contribuir para o desenvolvimento do Brasil ou da colônia nikkei, havia a necessidade de aprenderem e dominarem o "idioma japonês" Para Ando, o "nissei ideal" era "aquele que tivesse incorporado exatamente a metade de cada uma das culturas, japonesa e brasileira, e que falasse, lesse e escrevesse fluentemente tanto o japonês como o português". Em outras palavras, alguém de "assimilação intermediária" em relação ao Brasil.

Uma das características do modelo de Ando é que o papel da língua japonesa, até então de formação de caráter (virtudes japonesas, espírito japonês, etc.), se altera, adquirindo um papel meramente funcional e técnico, ou seja, de transmissão de habilidades e talentos. Em outras palavras, Ando negou a "função de formação de caráter"19 do idioma japonês, a partir do ponto de vista de que "o nissei é um brasileiro nato"

Com base nesse modelo, surgiu mais tarde o "movimento para publicação, no Brasil, de livros didáticos em japonês" Embora não seja o caso de aqui entrarmos em detalhes do que vinha a ser tal movimento, vou, brevemente, a seguir, pincelar os seus principais tópicos ${ }^{20}$ :

(1) “As crianças nikkeis são brasileiros autênticos e seu destino é sustentar a glória brasileira" Nesse sentido, são inapropriados os livros didáticos voltados para a "formação de japoneses" (como, por exemplo, os livros didáticos oficiais japoneses, editados e publicados no Japão);

19. O "movimento para publicação, no Brasil, de livros didáticos em japonês", que foi conduzido por Ando, tinha como objetivo o ensino do japonês, mas usando o colônia-gô, para amadurecer/maturar o "espirito da colônia" ou a identidade do colônia-jin e por isso, nesse sentido, não é que excluísse/renegasse por completo a função formadora de caráter da língua japonesa.

20. Extraídos do folheto Nihongo Kyôkasho Kankôkai no Jyõkyô (Situação Atual da Associação de Edição e Publicação de Livros Didáticos em Japonês), 1959. 
(2) O objetivo do ensino do japonês aos nisseis é "a formação de indivíduos que, tendo como base o caráter do povo brasileiro, cultive o peculiar espírito da colônia nikkei, radicada no Brasil, de modo que se dediquem e se esforcem em prol da prosperidade do Brasil";

(3) Evitar enfatizar ações peculiares próprias dos japoneses e renegar o "espírito japonês conceitualizado".

Com base em tais premissas, livros didáticos apropriados ao colônia-jin passaram a ser editados e publicados na "colônia nikkei" e efetivamente usados em escolas de japonês.

Há que se ressaltar que a língua descritiva empregada nesses livros didáticos não era o japonês padrão, mas uma língua híbrida, uma mistura de japonês e português, a chamada colônia-gô, principalmente em cartilhas voltadas aos alunos mais novos ${ }^{21}$ Isso demonstra claramente a determinação e a personalidade dos imigrantes de então, que tinham optado por permanecer em definitivo no Brasil, com uma nova identidade, a de "japonês do Brasil", isto é, de colônia-jin. A campanha de editar e publicar livros didáticos no Brasil nada mais era que uma "campanha de educação étnica japonesa", objetivando formar japoneses étnico(colônia-jin).

Pode-se dizer, ainda, que o modelo proposto por Ando pode ser considerado uma migração do modelo tradicional wakon hakusai para o modelo hakkon wasai. Evidentemente, Ando não quis dizer que o japonês devesse ser considerado uma "língua estrangeira", mas, sim, colônia-gón ${ }^{22}$, uma língua à parte do "japonês do Japão", isto é, "japonês do Brasil=língua herdada especial" Tampouco ele quis dizer que o ensino do colônia-gô só servia, meramente, ao propósito prático/funcional e técnico. Sem dúvida, ele sabia que se esperava e se previa que um dos objetivos de seu ensino era a função de "formação de caráter" (maturação de identidade) do colônia-jin.

O modelo genuinamente wakon hakusai só surgiria nos anos 80 , quando o japonês deixa de ser utilizado como língua do dia-a-dia em casa, na vizinhança ou em atividades

21. Mais tarde, o emprego do colônia-gô nos livros didáticos foi criticado sob os mais variados pontos de vistas. A primeira crítica partiu dos intelectuais da colônia nikkei (em fins da década de 50 e início da década de 60). Dizia que a criança nikkei era um "estrangeiro (brasileiro)" e que, portanto, o ensino da língua japonesa era como lhe ensinar uma língua estrangeira e que, como tal, deveriam ser adotadas "didática e pedagogia corretas". A segunda crítica era por parte de especialistas em língua japonesa, enviados do Japão (década de 70). Dizia que deveria ser adotado um japonês autêntico, que os japoneses do Japão pudessem compreender. MORI, Koichi. "Burajiru no Nihonjin to Nihongo (Kyôiku)" ("Os Japoneses do Brasil e o Idioma Japonês (Educação em Japonês))". In Kokubungaku: Kaishaku to Kanshô (Estudos Vernaculares: Interpretação e Apreciação), 2006, v. 71 , n. 7.

22. Havia, além de aulas de japonês, aulas de Desenho, Trabalhos Manuais, Música/Canto e, ainda, eventos como apresentações teatrais, gincanas poliesportivas, o que conta de maneira eloqüente a "realidade" de que o modelo era destinado mais para a "formação de japoneses" do que propriamente para ensino de língua japonesa. 
de sociedades étnicas, fazendo surgir a consciência do "japonês como língua estrangeira" e o paradigma de que o objetivo do ensino do japonês não é a "transmissão cultural", mas "difusão cultural". Ainda assim, foi dificil, do ponto de vista sentimental e afetivo, que os imigrantes ou os nikkeis considerassem o japonês meramente uma "língua estrangeira" e apagassem por completo a sua função de formação de caráter (de amadurecer a identidade).

Isso porque, com maior ou menor intensidade, sempre houve a projeção dos sentimentos dos "pais", imigrantes japoneses da primeira geração, no "caráter/personalidade" dos "filhos", os nisseis aqui nascidos. Um exemplo: surgiu, nos anos 90, um novo modelo, o do "ensino do japonês ao mesmo tempo como língua herdada e estrangeira", isto é, era um novo modelo de educação dos filhos(novo modelo de ensino de japonês), mas totalmente contraditório por si. Como uma língua poderia ser herdada e, ao mesmo tempo, estrangeira? Tal contradição deve ter surgido ao se mesclar o sentimento (identidade) dos imigrantes e dos nikkeis em relação ao "japonês" com uma consideração mais técnica, ou seja, a necessidade de se ensinar o "japonês ainda que como língua estrangeira", no momento em que ele estava desaparecendo dos lares, da vizinhança e das sociedades étnicas.

\section{Conclusão}

A história da imigração japonesa no Brasil, no tocante à educação de seus descendentes aqui nascidos, foi um processo de como reconhecer a categoria do nissei (se japonês, brasileiro ou colônia-jin) e, na esteira disso, negociar, reconciliar e aglutinar o que era "ser japonês (língua japonesa)" e "ser brasileiro (língua portuguesa)" numa trajetória repleta de conflitos, contradições e confrontos. Pode-se dizer, ainda, que os diversos modelos de educação criados pelos imigrantes eram ao mesmo tempo uma declaração de etnicidade, bem como um objetivo a ser alcançado. Os isseis criaram esses modelos com dificuldade, considerando cada situação em que eles próprios e os nisseis se encontravam em cada momento de sua criação. Pode-se dizer que representam a própria identidade dos imigrantes japoneses isseis, projetada sobre a figura do nissei ideal.

Pode-se dizer, ainda, que tais modelos foram estruturados, sempre em conexão com as estratégias de sobrevivência ou as identidades adotadas pelos imigrantes isseis em cada uma das instâncias por eles vividas, levando em consideração até que ponto se podia permitir a assimilação do nissei à sociedade brasileira ou a sua aproximação à cultura brasileira. Em outras palavras, tratava-se de se demarcar onde parar o processo de assimilação e, na esteira disso, até que ponto negociar ou aglutinar o português e o japonês e, feito isso, que funções (papéis) atribuir a cada uma dessas línguas.

Por outro lado, no entanto, a figura do nissei, idealizada no modelo bilíngüe de educação, que já nascera ele próprio com dificuldade, era, em um sentido, uma figura 
humana contraditória, dividida no seu íntimo. Da mesma forma, a preparação de terreno para que esse modelo fosse levado ao cabo também foi cercada de dificuldades geradas pelas limitações dos próprios imigrantes. Inclusive, muitas vezes aconteceu de quando o modelo estava prestes a ser posto em prática e estaria para surgir uma formação do nissei ideal, mudavam-se as condições e o próprio modelo acabava por perder sentido. Esses confrontos, contradições e conflitos estavam presentes não só nos isseis, que criaram os modelos, mas também nos nisseis, objeto de aplicação dos mesmos, devido aos confrontos, contradições e conflitos inerentes a cada uma de suas nacionalidades.

Os episódios aqui citados são apenas algumas facetas dos inúmeros confrontos e conflitos enfrentados pelos imigrantes e seus descendentes. Migrar transpondo a fronteira de um país significa dividir-se entre duas nações, enfrentar inúmeras contradições, conflitos e confrontos, inerentes à mudança de contextos e conciliá-los a cada momento, buscando uma nova identidade e um novo modelo de vida e continuar a viver uma estratégia de sobrevivência que esteja de acordo com essa nova identidade e novo modelo de vida.

Em meio à globalização cada vez mais acelerada, cresce vertiginosamente o número de pessoas que deixam os países/regiões em que nasceram e tentam uma nova vida em um novo país, em uma nova região. Esses "imigrantes" também têm enfrentado os mesmos problemas aqui descritos. A partir da metade dos anos 80 , muitos descendentes de imigrantes japoneses migraram para o Japão como "mão-de-obra" e em meio a duas tendências; a primeira, a da permanência definitiva no Japão e outra, de vai-volta entre o Brasil e o Japão, acabaram transferindo os problemas que outrora ocorreram no Brasil para o Japão ou para outros espaços transnacionais. Nesse sentido, pode-se dizer que a "história da imigração japonesa em torno da educação de seus filhos" ainda não acabou.

\section{Bibliografia}

ANDÔ, Zenpachi. Nisei to Nippongo Mondai - Koronia no Ryôshiki ni Uttaeru ( $O$ Nissei e a Lingua Japonesa: Um Apelo ao Bom Senso da Colônia), São Paulo, edição própria, 1958.

Kikanshi Gakuyû (Boletim Amigos do Estudo), São Paulo, São Paulo Gakusei Renmei (Sociedade Paulista de Estudantes), 1936.

Seishi Yûgaku no Tebiki (Manual para Estudar em São Paulo), São Paulo, Seishi Gakusei Kishukusha Kyôkai (Associação dos Internatos Estudantis da Cidade de São Paulo), 1938.

NAKATO, Yasue. "Burajiru Shakai ni Okeru Gengo no Jittai" ("A Situação Real da Lingua na Sociedade Brasileira"). In Kokubungaku Kaishaku to Kanshô (Estudos Vernaculares: Interpretação e Apreciação), v. 71, n. 7, 2006. 
Nihongo Kyôkasho Kankôkai no Jyôkyô (Situação Atual da Associação de Edição e Publicação de Livros Didáticos em Japonês), Nihongo Kyokasho Kanko Kai (Associação de Edição e Publicação de Livros Didáticos em Japonês), São Paulo, 1959. HANDA, Tomoo. Imin no Seikatsu no Rekishi (O Imigrante Japonês - História de Sua Vida no Brasil), Tóquio, Editora Ie no Hikari Kyokai, 1970.

Burajiru Nihon Imin Nanajûnenshi (História dos 70 Anos da Imigração Japonesa no Brasil), São Paulo, Burajiru Nihon Imin Nanajûnenshi Hensan Iinkai, 1979.

Burajiru Nihon Imin Hachijûnenshi (História dos 80 Anos da Imigração Japonesa no Brasil), São Paulo, Burajiru Nihon Imin Hachijûnenshi Hensan Iinkai, 1990.

Burajiru Jihô (Atualidades Brasileiras), São Paulo, Editora Burajiru Jihôsha, 1921.

Burajiru Nenkan (Anuário Brasileiro), São Paulo, Editora Burajiru Jihôsha, 1939.

MAEYAMA, Takashi. Imin no Nihon Kaiki Undô (O Movimento dos Imigrantes para Retornar ao Japão), Tóquio, NHK Books, 1982.

MAEYAMA, Takashi. Ethnicity to Burajiru Niekkeijin- Bunkajinruigakuteki Kenkyu (Estudo Antropológico: A Etnicidade e os Nipo-Brasileiros), Tóquio, Editora Ochanomizu Shobô, 1996.

MAEYAMA, Takashi. Ihò ni Nihon wo Matsuru (Santificar o "Japão" em um País Estrangeiro), Tóquio, Editora Ochanomizushobo, 2001.

MORI, Koichi. "Burajiru no Nihonjin to Nihongo (Kyôiku)" ("Os Japoneses do Brasil e o Idioma Japonês (Educação em Japonês)" In Kokubungaku: Kaishaku to Kanshô (Estudos Vernaculares: Interpretação e Apreciação), 2006, v. 71, n. 7.

WAKO, Shungoro. Baurû Kannai no Hôjin (Japoneses da Região de Bauru), 1939. 